\title{
JOÃO PEDRO DA CÂMARA, UM FRONTEIRO OLVIDADO.
}

Somos um país que se distingue de logo, no quadro físico da América do Sul, pelo potencial representado no espaço geográfico. Nem sempre, no entanto, foi assim. No primeiro século de nossa formação, éramos como um Chile em grandeza territorial. Representávamos uma longa faixa de terra que principiava no idelta amazônico e vinha terminar em Laguna, no sul de Santa Catarina. O ajuste de Tordesilhas, celebrado em 1493, garantira ao velho Portugal que devassava mares e novos mundos num afã sem símile em: todos os tempos históricos, apenas aquela extensa costa atlântica, que, a certos aspectos, recordava o território metropolitano. Não havia, em conseqüência, como na Ibéria, um interior de proporções ponderáveis, o que não significa que, aqui e ali, pela própria imposição da geografia regional, em decorrência dos recortes e curvas litorâneas, êsse interior não se apresentasse com certas dimensões apreciáveis. Eramos, na verdade, uma faixa de terra que acompanhava o mar e sôbre a qual se disputaram o senhorio portuguêses, franceses, inglêses e holandeses.

A ampliação, que se seguiu à sondagem, esta iniciada logo no primeiro século do empossamento português, modificando totalmente o diploma inicial, foi, aos poucos, compondo uma nova carta política que, por fim, em 1750, veio a ser definida em suas linhas centrais e só no século $\mathbf{X X}$ alteradas pela legalização do último episódio dessa expansão, o episódio do Acre, que repetiu aquêles mesmos lances serenos de ocupação cordial da terra pela sua exploração econômica e aquêles mesmos lances militares das jornadas contra o estrangeiro que nos disputava o espaço e concorria na imposição de soberania. A expansão efetuada sem descanso no decorrer de quatro séculos, assegurando-nos uma base física imensa e condições e possibilidades econômicas que ainda não foram medidas na sua exata profundidade e extensão, assegurou-nos, do mesmo passo, uma característica social, na paisagem do continente. E' que lhe proporcionamos magnífica galeria de tipos como o bandeirante paulista, o criador nordestino, o gaúcho-soldado da fronteira-sul, o minerador das gerais, de Goiás e do Mato Grosso, o sertanista-fluvial da Amazônia, o senhor de engenho das campanhas contra o hereje de $\mathrm{Ba}$ távia. 
Todo êsse drama tão bem vivido de criação das bases físicas decorreu, no entanto, a cabe aqui a pergunta, de um propósito do Estado ou da iniciativa do próprio colono, que cêdo se afirmara na terra e dela se ia assenhoreando à medida que os imperativos econômicos the impunham a atitude?

A tese do planejamento, em grande estilo, da execução de uma política de desrespeito ao tratado de Tordesilhas, visando à criação de um império luso-americano que sucedesse ao império montado na India, mas que, à concorrência voraz de outros povos europeus, entrara a perder-se, esgotando as energias da mãe-pátrię, não é uma tese de recusar-se. Como não é igualmente de recusar-se a outra, que explica o esfôrço da expansão pela vontade única ou maior do colonizador. $\mathbf{E}$ isso porque, bem pesadias as razões em que se alicerçam, examinados os fatos históricos, nas suas minúcias, há de concluir-se por que, efetivamente, em muitas oportunidades, o bandeirante agiu sem obedecer senão aos seus próprios anseios, como em outras foi evidente a diretriz-imperialista decretada de Lisboa. O que não é possível, no entanto, é deixar de reconhecer que a política oficial objetivou sempre manter, para a soberania portuguêsa, na expansão, o que ia sendo descoberto, explorando e incorporando ao Brasil em formação. Nesse particular, a documentação é a mais abundante, revelando mesmo a existência de um estado d'alma, de uma constante a tal respeito, estado d'alma e constante jamais perturbados ou alterados.

Quando, pois, no século XVIII, o bandeirante paulistano, aquếle da "Raça de Gigantes" de que Saint Hilaire nos falava cheio de espanto e de adimiração, atingiu o Mato Grosso, busc'ando outra área aurífera de onde o emboaba não o expulsasse, e avizinhandose do espanhol de Santa Cruz de la Sierra, dos Moxos e Chiquitos, da gobernación do Paraguai, o Estado não the deu ordens para abandonar as posições que ocupava. Antes, animou-o no empreendimento, assegurou-lhe condições de vida, defendendio-o, legalizando a conquista pela presença das autoridades civis, militares e eclesiásticas. E não cedendo às imposições do vizinho, manteve o novo território e o grupo social que incorporava à conjuntura econômica, executando política de envergadura, pela ação hábil de diplomatas e através de uma série de homens de govêrno que se sagraram legítimos estadistas, legítimos lusíadas.

*

\section{A Conquista do Oeste e as Minas de Cuiabá e Mato Grosso.}

O descobrimento mais pormenorizado, a exploração e ocupação permanente do que é hoje o Estado de Mato Grosso foi façanha iniciada com a entrada de Antônio Pires de Campos, no ano 
de 1718. O sertanista procurava os Caxiponé, para os mercados paulista e mineiro. Ao regressar, encontrou a bandeira de Pascoal Moreira Cabral que marchava com os mesmos objetivos. Indicou a posição que ocupara e onde o gentio the fizera cerrada oposição. Moreira Cabral alcançou-a. E com os de sua companhia, descobriu o ouro do Coxipó-mirim, que Miguel de Sutil, mais adiante, nas regiões cuiabanas, iria encontrar em maior porção (1).

A aventura criadora e descobridora de Pires de Campos e Moreira Cabral não era a primeira. Já no século XVII, por 1680, grupos de bandeirantes, chefiados por Pascoal Moreira Cabral Leme e Andiré de Zunega, haviam atingido o sul de Mato Grosso, a Vacaria regional, estabelecendo uma posição fortificada às margens dıo Miranda, em Mbotetéu e na qual resistiram durante anos à investida dos Paiaguá. Descoberto o ouro, a corrida para as novas minas processou-se com aquela mesma impetuosidade por que se registrara nas Gerais. E com o rush, as medidas acauteladoras do fisco, que o Capitão-General Rodrigo César de Meneses, governador de São Paulo e Minas veio estabelecer, num zêlo quase policial que ia provocando o abandôno de Cuiabá e a internação dos mineradores que fugiam aos rigores da autoridade preponılierante. Alcançara-se, em conseqüência, nova zona de mineração, aquela que recebeu o nome de Mato Grosso, mais tarde estendido a todo o território. Cuiabá ia em breve obter a predicação de vila, com câmara municipal que deliberou abrir livro próprio para que se inscrevessem todos os acontecimentos que, pelos anos adiante, merecessem permanecer na memória da posteridade. O povoamento e a exploração econômica da região, apesar dos rigores fiscais do Estadio, não se interrompeu. Porque, aos novos achados em outros distritos, abriram-se as explorações, montaram-se os arraiais, criava-se uma vida que não era mais aquela das tribos errantes que is ocupavam antes da chegada do bandeirante (2).

As Minas de Cuiabá e Mato Grosso proporcionavam lucros inéditos. Havia riqueza mineral por tôda parte. As estatísticas re-

(1). - A história do descobrimento das minas matogrossenses e sua exploração está feita nas suas linhas centrais graças aos ensaios e contribuições de Vergílio Correa Filho, nas suab duas "Monografias Cuiabanas", dedicadas à evolução do erário e à cata de ouro e diamantes, editadas em São Paulo; e a Afonso Taunay, na monumental "História das Bandeiras Paulistas", tomo $\mathbf{X}$, São Púulo, 1949. A crônica regional, elaborada nos idos coloniais e posteriormen. te por Felipe José Nogueira Coelho, José Barbosa de Sá, Joaquim da Costa Siqueira, Beaurepaire Rohan, Barão de Melgaço, é, de outro lado, fonte preciosa que não pode ser ignorada pelo vasto informe esclarecedor que delas consta e foi por aquêles historiadores aproveitada.

(2). - Sôbre a presença paulista no sul de Mato Grosso, numa antecipação evidente ao esfôtço de descobrimento e exploração do ouro e dos diamantes, antecipação que no fim de contas nada possui de extraordinário pois que é página integrante da expansão que os homens de São Paulo realizavam desde o sé. culo XVI, é definitivo o estudo pertinente de Afonso Taunay,- tomos IV e VI da obra citada. 
velaram arrecadações espantosas. Segundo Washington Luís, só o ouro cuiabano contribuiu, em oito anos, isto é, de 1721 a 1728, com 183.618 quintos, o que permite chegar à conclusão de que, nesse período, Cuiabá produzira 224.000 arrobas e $5581 / 2$ oitavas. As notícias que circulavam por tôda parte falavam de ouro sem fim. Calculara-se que os veios alimentariam os que o buscavam por mais de vinte anos. Dizia-se que Miguel Sutil, em menos de um mês conseguira 400 arrobas. As Gerais seriam, assim, muito inferiores às novas minas, que estavam provocando um interêsse ainda maior, o que queria dizer, movimentação incessante sôbre elas, das multidões que se deslocavam do litoral ou das próprias Gerais. Para lá acorriam aventureiros, clérigos, que deixavam as obrigações religiosas, velhos servidores do Estado, homens de prol das Capitanias vizinhas, bandeirantes que entroncavam nos primeiros fixadores da grei paulistana, gente enfim de tôda espécie. Já em 1 de janeiro de 1727 , por tudo isso, o povoado que originara aquela impetuosa marcha para Oeste, graduario na condição de viIa, era solenemente instalado pelo Capitão-General Rodrigo César de Meneses (3). Compunham o burgo, então "148 fogos, alguns cobertos de telha, os mais de palha e capim" (4). A população vivia maleitada. A carestia era espantosa. Uma galinha custava três oitavas, isto é, dez gramas de ouro, ou sejam $4 \$ 500$. Em valor atual, $\operatorname{Cr} \$ 900,000$. Uma dúzia de ovos, $2 \$ 500$, isto é, $\operatorname{Cr} \$$ 500,00 ! (5).

O povoamento prosseguiu, destarte, sem medida, apesar das mil providências que foram sendo decretadas para que não ocorressem ali os mesmos incidentes de que foram teatro as Gerais. As concessões de mercês régias aos que procuravam o novo Eldorado, visavam, é certo, incentivar o descobrimento das minas. Visavam também galardoar os que se fizessem credores das concessões régias, dando à sociedade, que se constituia com elementos tão heterogêneos, meihores fundamentos.

Nesses primeiros tempos, o acesso operava-se por terra e por via fluvial, em monções cercadas de perigos ante os assaltos dos Paiaguá, os quais mais de uma vez as destruíram, pondo em pânico os grupos que buscavam a região mineira.

Dirigindo-se para o Norte, os sertanistas conseguiram alcançar outras águas fluviais que não eram as da bacia platina. Essas águas eram as do Guaporé que os levou ao Mamoré, por fim ao

(3). - Sôbre êsse quadro da vida matogrossense é de consultar-se os cronistas já referidos, mais o livro de Washington Luís, "A Capitania de São Paulo", em que, examinando minudentemente o que foi o govêrno de $D$. Rodrigo César de Menezes, esclareceu muito acêrca do período histórico durante o qual aquêle administrador exerceu suas atividades em Cuiabá.

(4). - Cf. Taunay, ob. cit., tomo 10, pgs. 40-41.

(5). - Cf. Taunay, ob. cit., tomo 10, pg. 49 . 
Madeira, e por êste ao Amazonas. O novo caminho, que exigia tanta coragem como o outro, pois que se fazia necessário vencer corredeiras perigosas no Madeira, fôra descoberto em 1742 por Manuel Felix de Lima. João Leme do Prado, em 1748 repetira a façanha. João de Sousa de Azevedo, que em 1746 descobriu outro caminho pelo Arinos-Tapajós, aproveitara-o em 1749 trazendo às minas, com a nova sensacional da possibiliłade de alcançar o Atlântico sem a necessidade de chegar primeiro a São Paulo, abastecimentos que valiam fortunas numa época em que poucos podiam dar a devida atenção às tarefas agrárias, dominados que andavam pelas catas de tamanhos rendimentos. A fome, de quando a quando, batia nos arraiais, Cuiabá inclusive. A nova via assegurando facilidades, vinha suprir as deficiências que se observassem no abastecimento feito pela via paulista.

A marcha para Oeste fôra iniciada com maior vigor no século XVII. Levara às Gerais. Levara à hinterlândia amazônia. Levara aos sertões nordestinos. Levara aos platôs do Paraná e às aldeias jesuíticas do Guiará. Com o descobrimento das minas do Cuiabá, do Mato Grosso e as dos Goiases, completara-se a expansão, criando uma fronteira inteiramente nova. A abertura do caminho do GuaporéMamoré-Madeira, ligando a bacia ro Prata à do Amazonas, assegurava a essa fronteira uma continuidade que precisava ser mantida. Ademais, estava próximo, muito próximo, um vizinho que poderia pôr em perigo a estabilidade das posições ocupadas e dos estabelecimentos que se organizavam ua base daquela exploração econômica dos veios auríferos.

Ao iniciar-se a expansão com o descobrimento das minas, o bandeirante sentira o perigo. Tomara-se de cautelas. Logo em 1720 fôra, de ordem régia, mandado precaver-se para evitar choques com o confinante. Que essa precaução não significasse, porém, suspensão do rush. Ao contrério, era conveniente até levantar um povoado que servisse para embaraçar a presença dos espanhóis, como era conveniente iniciar a cultura da terra que fôsse posśvel mantê-la em definitivo. O Capitão-General Rodrigo César, de seu lado, pedia a atenção constante dos mineradores para o assunto, a fim de que não se registrassem contendas que pudessem pôr em grave risco aquêles mananciais fabulosos. Falando para Lisboa, na base das informações que lhe chegavam da zona de ação, esclarecera que a distância entre as situações mineiras e os núcleos espanhóis era grande: três meses de viagem, por caminhos difíceis a que não poderia resistir quem por êles se aventurasse. O Governador da Colônia do Sacramento, cheio de receios em face de boatos que the chegavam ao conhecimento, vindos de Buenos Aires, já vislumbrava acontecimentos sensacionais. D. Rodrigo César, fa- 
lando para Lisboa, apressara-se a esclarecer que estivessem sossegados. Porque a fronteira não seria violada. Os choques previstos não ocorreriam.

A expansão luso-brasileira face à expansão hispano-americana. As velhas diferenças peninsulares emigraram para o Novo Mundo. Não é só no Prata ou na Amazônia que se luta pela soberania luso-brasileira.

A vizinhança das minas com os territórios de soberania espanhola exigia, no entanto, se não rigoress excepcionais, pelo menos cautelas, muitas cautelas. $\mathrm{O}$ vizinho não esquecia a destruição do Guairá. A Colônia do Sacramento, levando ao Prata as quinas portuguêsas, era outra página de afronta aos seus brios. $O$ vizinho não se apercebera, porém, de pronto, da permanência do bandeirante, que êle com tôdas as fôrças, pelas perdas que lhe inflingia de quando em vez, e pela ousadia porque lhe penetrava o território para desbravá-lo e incorporá-lo ao novo estado político que ajudava a construir no Novo-Mundo. A própria chegada à zona de mineração não fôra sentida prontamente. E só alguns anos após o início do rush é que se informara da façanha. Até então, os receios em que andava referiam-se ao trecho norte, no $\mathrm{Ma}$ deira-Mamoré-Guaporé, a que chegara, em 1722, vindo de Belém, o capitão Francisco de Melo Palheta, com 130 companheiros e 40 bôcas de fogos. Na oportunidade, os missionários de Moxos, visitados pelo sertanista da Amazônia, apelaram para as autoridades em Madrí, pleiteando autorização, que por fim lhes foi concedida, para que armassem o gentio, pondo-os em condições de reagir a qualquer nova incursão dos mamelucos brasileiros. Porque, para êles, o sertanista que os visitara seria apenas um tomador de posição, um verificador de situação para futuros avanços (6).

À nova sensacional de que os bandeirantes de São Paulo realizavam a exploração das minas em área que podia ser de Espanha, começaram, pois, a preocupar-se. O governador paraguaio José de Antequera fêz as primeiras sondagens sem êxitos. Em 1737, no entanto, já seguros do que os mineiros estavam produzindo como riqueza econômica ou como empreendimento político sôbre uma vasta pretensão de terra que incorporavam assim ao patrimônio luso-brasileiro, cogitaram de uma ação militar. As províncias de Tucuman, Paraguai e os territórios da audiência de Charcas, hoje Bolívia, em

\footnotetext{
(6). - Sôbre a expansão política que os luso-brasileiros realizavam em detrimento dos interêsses territoriais de Espanha, cf. Vałcas Galindo, "Limites ezuatorianos-peruanos", tomo I, capítulo intitulado - Avance de los portugueses sobre Maynas, Quito, 1902. A documentação que aí se divulgła é completada agora por Pablo Pastells, "Historia de la Companhila de Jesus en la Provincia del Paraguay", tomos VI, VII, VIII, continuação organizada por F. Mateos, S. J., Madrí, 1946-1949.
} 
especial Santa Cruz de la Sierra, sentiam-sc em perigo. Os jesuitas de Chiquitos e de Moxos, cujas aldeias iam aos poucos procurando aproximar-se dos arraiais de mineração, alarmaram-se também. Um capitão de fragata que estivera prisioneiro no Rio de Janeiro, Juan Antonio de la Colina, volvendo a Buenos Aires, informava, em fins dêsse ano de 1737 , sôbre o que valiam as minas e o que significavam contra os interêsses e a soberania espanholas. Essas informações, apesar dos exageros que expressavam, causaram inquietação. Logo a 8 de outubro de 1738 foi expedida cédula real mandando recuperar a região (7). Não se the deu cumprimento. Nos anos seguintes, continuram as notícias alarmantes: prosseguia a expansão luso-brasileira. Cuiabá já era um núcleo urbano maior que o Rio de Janeiro e a cidade do Salvador. . . Nela viviam 5.000 pessoas. . . No distrito das minas haveria cêrca de $40.000 \ldots$ A destruição da nova colônia do Mato Grosso só seria possível com a mobilização die grandes fôrças: a bugrada das missões devia constituir um contingente apreciável (8). A emprêsa, porém, seria mais fácil partindo de Assunção. Um traidor português, de nome Francisco Esteves de Cervera, egresso do Brasil, onde vivera largo tempo, indicara maiores detalhes, prontificando-se mesmo a conduzir as fôrças encarregadas de proceder à recuperação. Em paga a tamanhos serviços, que Sua Magestada Católica o nomeasse guarda-mór de tôdas as minas. Outro português, êste residente em Buenos Aires, de nome Manuel Martins, dizendo-se conhecedor da região, pelo contacto que com ela tivera pelos anos de residência alí, forneceu indicações mais precisas. Em 1740, um grupo de paulistas chegou à missão de São Rafael, no Jaurú, para tentar aproximação comercial com os jesuítas, que possuiam gado. Presenteon-a com paramentos para os altares. Foi bem recebida, mas fracassou nos objetivos mercantis. Outros grupos, a seguir, esperançados de êxito, procuraram vencer a resistência dos inacianos. Em vão. As ordens emanadas de Santa Cruz de la Sierra, de Assunção, de Buenos Aires eram positivas: nenhuma relação com os intrusos de Cuiabá e Mato Grosso.

Em 1741, todavia, às novas mais incisivas de que o bandeirante estava agora senhor de todo aquêle mundo tão rico, tudo se alterou. Abria-se, na oportunidade, às denúncias partidias dos jesuítas de Maynas, no Perú, una devassa de largas proporções a propósito da expansão luso-brasileira nó vale amazônico. A penetração no Mato Grosso fôra, então, alegada também, passando a interessar no inquérito que estava revelando a existência de um imenso perigo para os interêsses de Espanha em seus territórios coloniais

(7). - Cf. Pastells, ob. cit., tomo VII, pgs. 291-293.

(8). - Cf. documentação em Pastells, ob. cit., tomo VII. Também Taunay, ob. cit,, vol. 10 , pgs. $305-307$. 
com aquela aventura a nosso cargo, aventura que parecia, antes, um propósito político da maior envergadura. Até aquêle instante, é certo, a não ser no sul, onde se movimentavam as autoridades de quando em vez, na disputa pela Colônia do Sacramento, apenas os jesuítas no seu afã catequista e nos seus pronunciamentos cívicos porfiavam na defesa da soberania espanhola en face da irradiação lusobrasileira. Nesse particula:; assinalando com detalhes o que foi êsse esfôrço verdadeiramente admirável, Constantino Bayle, eminentíssimo historiador da ação missionária espanhola nas Américas, e F. Mateos, também historiador da aventura jesuítica do Novo Mundo, já o indicaram nos aspectos de pioneirismo da emprêsa e no conjunto da ação dinâmica de que êle realmente se revestiu. Cometimento da maior envergadura, o esfôrço dos jesuítas espanhóis em Maynas e entre os Moxos e os Chiquitos, em Charcas, portanto, tem muito de admirável. Não fôra o trabalho que realizaram, vigiando o bandeirante-povoador, coordenando a multidão gentia para servir à soberania de Espanha, mantendo, através das aldeias que montaram, essa mesma soberania, ep securamente, a expansão paulista e a amazônica teriam ampliado em maior extensão o território brasileiro.

O inquérito procedido em Assunção e em Santa Cruz de la Sierra, confirmou, porém, as notícias esparsas (9). Foram ouvidos sertanistas brasileiros aprisionados ou que já viviam em território espanhol. Foram ouvidos os inacianos das aldeias dos Moxos e Chiquitos. Um verdaideiro estado de alerta criou-se em tôda a fronteira, indecisa, imprecisa, mas que prometia um futuro animado. Governantes de Santa Cruz de la Sierra e de Assunção mostravamse inquietos, intranqüilos. $O$ gentio Payaguá criara insegurança, pondo em sobressalto espanhóis e paulistas. No ousio, haviam atingido Assunção, visando destruí-la. Sua presença, apesar de tudo, em meio aos dois grupos que disputavam a soberania dos vales auríferos, parecera útil, ao monarca espanhol, pois só assim se tinham mantido até o momento, sem choques mortais, luso-brasileiros e hispano-americanos. Em 1748 tôda uma série de cédulas régias e instruções expedidas pela Audiência de Charcas, pelo Vice-Rei do Perú e pelo Conselho das Índias visaram, a essa altura, impedir o prosseguimento da expansão bandeirante. Os luso-brasileiros, seguramente, pelo vale do Madeira ligavam-se ao Paraguai. Já se falava em localização de casais' de açorianos ncs distritos mineiros de Mato Grosso, o Mato Grosso como the chamavam (10).

(9). - A documentação referente ou que compõe êsse inquérito foi divulgada por Jayme Cortesão na 3a. parte do livro "Alexandre de Gusmão e o Tratado de Madrí, Antecedentes", tomo II, Rio; 1951, pgs. 35-51.

(10). - Cf. documentação em Pastells, ob. cit., tomó VII. 
Tôda essa prova que colhiam os espanhóis da ousadia do bandeirante não teriam pesado ponderantemente para levá-los ao tratado de $1750 \mathrm{com}$ concessões que conhecemos e são geralmente atribuídas à influência da rainha portuguêsa, espôsa ido rei? Por que, evidentemente, o que estava ocorrendo na região mineira do Cuiabá e do Mato Grosso significava que ali havia a mesma intensidade cívica que encontramos nas outras áreas de fricção entre espanhóis e portuguêses. Na documentação divulgada pelo padre Pablo Pastels, ora continuada pelo padre F. Mateos, encontra-se, por exemplo, uma informação que dá bem a medida dessa pujança cívica. Ao se encontrarem um grupo de missionários e de mineradores, discutiram acêrca dos direitos das duas corôas sôbre os chãos que pisavam. Alegaram-se títulos. Os bandeirantes, numa prova interessante de compreensão da gravidade do proilema, encerraram a disputa: os monarcas responsáveis por tais soberanias haveriam de entender-se para ajustar a dificuldade, enviado homens hábeis e cultos para turı apurar e tudo decidir. Enquanto tal não ocorresse, ficassem certos os jesuítas, aquelas terras permaneceriam sem dúvida em mãos dêles mamelucos. As velhas diferenças que emigravam da península continuavam vivas no Novo-Mundo (11).

Ora, se de parte dos espanhóis verificavam-se aquelas precauções, aquelas providências meio líricas para conter a expansão bandeirante, como se comportava o govêrno pcrtuguês? Não existiriam, realmente, os perigos da mera incursão predatória ou mesmo da ação, em grande estilo militar, dos espenhóis confiantes? As autoridades portuguêsas, como era natural, não se mostraram menos apercebidas que as espanholas. O movimento de irradiação partia de seus jurisdicionados. O que havia a fazer, portanto, era contê-la, desaprová-la, ou incentivá-la e garantí-la. E foi o que sucedeu (12).

Nos primeiros tempos, as notícias sốbre o Cuiabá e o Mato Grosso referiam-se apenas à fartura do ouro que estava sendo extraído e ao movimento das multidões que para lá se dirigiam. As preocupações oficiais, como era natural, cingiam-se aos imperativos políticos da ordenação legal da socieciade mineira a da organização econômico-fiscal da produção. Mais tarde, verificada a proximidade dos territórios espanhóis, ordenara $\mathrm{D}$. João $\mathrm{V}$ que todos os incidentes fôssem evitados. Os episódios que marcavam o momento nevrálgico no Sul, na região da Colônia do Sacramento, eram bastantes para a intranquilidade reinante. Nada, pois, de outros casos.

(11). - Cf. Pastells, ob. cit., tomo VII, pgs. 386-388.

(12). - Cf. Taunay, ob. cit., tomo 10, pgs. 305-307, 310-312. Cortesão, ob. cit., pgs. 64:80. 
Em 1740, o Ouvidor de Cuiabá, João Gonsalves Pereira, mandara proceder a sindicâncias sôbre a situaçãn da fronteira em face da vizinhança das missões jesuíticas que, falava-se, já estariam instalando novas posições ao norte do rio Cuiabá. A sinđicância fôra realizada por aquêle grupo de sertanistas que visitara a aldeia de São Rafael sob a chefia do paulista Antônio Pinheiro de Faria. De Lisboa desceram, então, ordens a fim de que se evitassem motivos aos espanhóis para um ataque a Cuiabá e Mato Grosso. Posteriormente, porém, em 1743 nova indagação fôra realizada sob a direção de José Barbosa de Sá, o cronista dos fastos cuiabanos. Ficara constatada a penetração missionária. Levado ao conhecimento de Sua Majestade D. João V, o assunto fôra proposto ao estudo do Conselho Ultramarino pedindo-se esclarecirnetitos aos Governadores de São Paulo e do Rio de Janeiro. Êste sugerira a fortificação da zona mineira; aquêle, entendia que seria suficiente o povoamento intensivo e permanente. A matéria, constituindo vasto processo, levou à sugestão de criar-se, nos Goiases e no Cuiabá, duas Capitanias. Dizia, a 29 de janeiro de 1748, o Conselho Ultramarino (13):

"No distrito de Cuiabá ainda reconhece o Conselho maior necessidade de Governador distinto e inteligente, e assim porque a extensão dêle ainda excedia a dos Goiás, e distância é muito maior, gastando-se de São Paulo à Vila do Cuiabá seis meses de trabalhosíssima navegação e dali ao Mato Grosso outro mês, como pela circunstância de confinar êste Mato Grosso com o Govêrno Espanhol de Santa Cruz de la Sierra, e com as Aldeias dos jesuitas Castelhanos dos Mochos e Chiquitos donde nasce que sobrevindo, como já sucedeu, e sucederá freqüentemente, contendas por causa dos confins e dá comunicação, è mui conveniente que ali haja um Governador capaz de responder e obrar com acêrto em semelhantes casos para evitar as desconfianças da Côrte de Madrí, sem perder o direito de nossos descobrimentos" (13).

\section{Era preciso fazer a Capitania do Mato Grosso}

"tão poderosa que contenha os vizinhos em respeito, e sirva de anti-moral a todo o interior do Brasil, para o que parece deparou a providência uma grande facilidade na comunicação que ali pode haver por água até a $\mathrm{Ci}$ dade do Pará" (14).

\footnotetext{
(13). - Cf. Cortesão, ob. cit., pgs. 127-130.

(14). - Cf. "Limites e Demarcações na Amazônia Brasileira. A Fronteira com as colônias espanholas", tomo II. Rio, 1948, pg. 98. As instruçōes foram publicadas na Revista do Instituto Histórico e Geográfico Brasileiro, tomo 55. 1a. parte. Rio, 1892 e Revista do Instituto Histórico de Mato Grosso, tomos 35-38. Cuiabá, 1947.
} 
Compreendia-se, está visto pelas razões invocadas, a gravidade da situação. A Capitania era a solução. Regulavam-se, de vez, as condiçõ€s existenciais da vasta região com o aparelhamento administrativo, ao mesmo tempo que se consolidava a fronteira garandindo-se também a ocupação da Amazônia. Os perigos a que estavam expostas as populações mineiras desapareceriam. A essa altura, ademais, ia em marcha a negociação ce limites que terminaria com o Tratado de Madrí. O princípio do uti-possidetis era, então, invocado para decidir sôbre as soberanias em choque. No caso do Mato Grosso, a Capitania significava a ocupação permanente, definitiva, portanto a posse sem interrupção e sem dúvida. A política oficial era uma política baseada no que hoje chamamos de geopolitica. Os homens de estado que estudavam os problemas coloniais no Conselho Ultramarino tinham a medida dos acontecimentos e a consciência exata do que era preciso fazer. A política oficial nessa fase visava à consolidação e à legalização do movimento expansionista. Às Capitanias do Mato Grosso e Goiás, iam seguir-se a do Rio. Negro e a de Santa Catarina e, mais adiante, a do Continente de São Pedro, hoje Rio Grande do Sul.

A Capitania de Mato Grosso. Que se objetiva com sua criação. Sentido geopolítico que se the pode atribuit. Rolim de Moura, magnífico executor da política que se pretende realizar em befício da ampliação do iespaço imperial no Brasil. O programa de povoamento e de fortificação.

Pela Carta Régia de 9 de maio de 1784 estabeleceu D. João V as duas novas unidades, assinalando, en? suas linhas gerais, os respectivos limites.

Para instalar o novo govêrno e assegurar-lhe aquelas condições vitais necessárias ao seu funcionamento, executando amplamente o pensamento régio, impunha-se a escôlha de um personagem capaz. A emprêsa era difícil, delicada. O homem escolhido foi D. Antônio Rolim de Moura Tavares, noneado a 25 de setembro de 1748. As instruções que the expediu S. Magestade, em 19 de janeiro de 1749, traçaram-lhe um programa de ação (15).

(15). - A correspondência de Rolim de Moura guarda-se na seção de manuscritos da Biblioteca e Arquivo Público do Pará e no Instituto Histórico e Geográfico Brasileiro. E' abundante e minuciosa. Esclarese os sucessos de seu govêrno, em particular os incidentes em que teve de agir contra os espanhóis agressores na defesa da Capitania. Sôbre êsse ataque, o ofício de 31 de maio de 1763, dirigido a Mendonça Furtedo, já então Ministro de Estado, é fundamental. Pastells, ob. cit., divulga no tomo VIII 2a. parte, documen. tação referente à correspondência trocada entre as autoridades espanholas da fronteira com Rolim de Moura a respeito da soberania luso-brasileria nos distritos de Mato Grosso. 
A sede do govêrno seria não no Cuidbá mas, no Mato Grosso pròpriamente dito, em unidade urbana a ser levantada nas proximidades do Guaporé, em local próprio por sua estabilidade, comodidade e defensibilidade; os habitantes cia Capitania fôssem alistados em ordenanças, devendo ser concedidás isenções e privilégios a quantas pessoas desejassem vir para o aumento da população e maior estabilidade da colonização; o gentio Payaguá, que tanta dificuldade criava à marcha do povoamento, fôsse tratado com tôda severidade, quando falhasse a política de persuação; igual tratamento devia ser dado aos Carijó que infestavam o caminho de São Paulo para Goiás; os índios mansos, en especial os Pareci, tratados cordialmente, assistindo-se-1hes com o que parecesse conveniente ou necessário à cordialidade com os uúcleos de civilizados. Nesse particular, a participação da Companhlia de Jesus seria imprescindível, pelo que o Capitão-general the solicitasse ajuda. $O$ Guaporé devia ser freqüentado, nele procedendo-se à pesca tão útil ao sustento dos povos como importante na tárefa de manutenção da soberania lusitana. O caminho para Atlántico, pelo Madeira, quando fôsse iniciado regular e legalmenté, não devia ser motivo para o abandôno do velho trânsito de canoas para São Paulo.

Quanto ao problema das fronteiras, das relações com os confinantes hispano-americanos e ao domínio sôbre o território da Capitania, recomendavam as instruções

$$
\begin{aligned}
& \text { "tôda a circunspeção e vigilância para evitar desa- } \\
& \text { venças com os vizinhos". }
\end{aligned}
$$

O comércio com os hispano-americancs devia ser evitado; as possíveis queixas do governador de Santa Cruz de la Sierra ou do Presidente da Audiência de Charcas, ficasse c Capitão-general na

"inteligência de que na matéria dêstes confins não há razão que deva fazer escrúpulo de excesso da nossa parte, antes o contrário".

É de assinalar-se, finalmente, êste trecho fundamental, que espelha os objetivos imperiais que animavam a alta direção do Estado português no tocante aos seus domínios no ultramar:

"deveis não só defender as terras que os meus Vassalos tiverem descoberto, e ocupado e impedir que os espanhóis se não adiantem para a nossa parte mas promover os descolrimentos e apossar-vos do que poderdes, e não estiver já ocupado pelos espanhóis, e evitando porém quanto fôr possivel não só tôda a violência, mas ainda a ocasião de dissabor pelo que toca as novas ocupações. 
E no caso que algum dos Governadores espanhóis vos faça instâncias, ou protestos, a êste respeito respondereis que sôbre as questōes se não pode tomar acôrdo entre vós, mas entre as duas Côrtes para onde cada qual de vos, deve mandar as suas representações".

D. Antônio Rolim de Moura a 17 de janeiro de 1751 empossou-se no govêrno em Cuiabá: viajara pelo áspero caminho das monções, partindo de São Paulo. Com as funções de Capitão-general iria acumular as de Chefe substituto da Comissão demarcadora de limites, no setor norte, criada em conseqǘncia do Tratado celebrado a 13 de janeiro de 1750 .

$\mathrm{Na}$ execução dos planos governamentais, houve-se com as cautelas e a decisão que o revelaram um estadista à altura do momento. Visitou a Capitania. Estabeleceu a sede da administração em Vila Bela da Santíssima Trindade, que fundou à margem direita do Guaporé, em sítio onde já havia o aglomerado urbano precursor, o sítio Pouso Alegre, arraial de Santana. Enfrentou os problemas que diziam respeito pròpriamente à organização de Mato Grosso, problemas múltiplos e variados. Enfrentou as questões delicadas criadas pela vizinhança espanhola.

Os jesuítas de Chiquitos possuiam, a essa altura, aldeias de catecúmenos nas terras banhadas pelo Guaporé. Rolim de Moura, compreendendo os perigos que havia com aquela expansão missionária, no fim de contas políticas também, instruído para dominar a navegação do Madeira, avançando sôbre a aldeia de Santa Rosa, circundando-a com estabelecimentos de mineiros e índios, escolhera a posição em que localisou a capital pur que esta lhe asseguraria o senhorio da região e lhe permitiria manter ligação limpa com a Amazônia, caminho para o Atlântico.

Tratara, depois, de tomar contacto com os jesuítas espanhóis para com êles assentar o destino das aldeiras em face do que fôra ajustado em Madrí. Os missionários, dando-se pressa em escapar aos rigores do Tratado, que mandava consultar os catecúmenos sôbre qual soberania desejavam permanecer, haviam tratado de mudar os três núcleos, São Simão, São Miruel e Santa Rosa, para lugares que o diploma declarava partes integrátites do império espanhol. Rolim de Moura, fingindo não compreender o motivo daquela movimentação, dera mesmo ordem acs moradiores das circunvizinhanças para que ajudassem os padres nił mudança. Todavia, os religiosos, que tão cordiais se mostravam nes primeiros momentos, recebendo, posteriormente instruções de seus superiores, inclusive do Vice-Rei do Perú, conquanto não regressassem aos sítios anteriormente ocupados pelas três aldeias, tinham passado a impedir que os luso-brasileiros ocupassem as posições abandonadas. Rolim 
de Moura, que trouxera ordens terminantes para valer-se da Companhia de Jesus na Assistência de Portugal rios trabalhos de conquista da multidão gentia e de preservação territorial da Capitania, apoiando-se então, na atividade de um jesuíta português, de nome Agostinho Lourenço, ordenara a imedista ocupação daqueles sítios. Visitara largo trecho da fronteira. E voitando a cartear-se com os jesuítas espanhóis, falara-lhes claro sôbre as terras, que eram de Portugal, e sôbre as pretensões que estavanı a exteriorisar.

E prosseguindo nas diretrizes que se traçara, apressara a política da ocupação, mandando guarnecer por um pequeno diestacamento o chamado "Sítio dos índios". Abandonara-o, todavia, devido às enfemidades locais e à falta de recursos financeiros para satisfazer as despesas. Ordenando depois a reocupação pela importância de posição que era preciso marier de qualquer modo, imaginara um ardil para avançar serenamente com seus homens: a guarda seria substituída de três em três meses, fizera público, mas o cabo que a comandava tinha ordens para, $\mathrm{cm}$ vez de fazer regressar a Vila Bela o descamento rendido, remetê-lo a Santa Rosa, alí plantado nova guarnição. O primeiro ficaria com dez a doze homens, e o segundo com trinta a quarenıa, ambos servidos de "pecinhas de amiudar".

O estabelecimento não era suficiente. Fazia-se preciso outro. Situou-o em Nossa Senhora da Boa Viagem, como garantia da navegação para o Madeira. Encarregou da fundação o dr. Teotônio da Silva Gusmão. Com êsses estabelecimertos, parecia-lhe perfeitamente assegurado a soberania luso-brasileira. A carta régia que franqüeara a navegação do Madeira, cogitara da fundação do núcleo. Mendonça Furtado, em 1752, lembrara a tuadação.

Com tôdas aquelas providências, a orla lindeira ficara marcada pelos postos de ocupação acima de Vila Bela, em direção às cachoeiras do Madeira, cortando-se o passo cos espanhóis .

A anulação do Tratado de Madrí em 1761, veio, porém, abrir à Capitania uma nova fase de inquietações. Porque os confinantes hispano-americanos não demoraram em mever-se com o objetivo de reaver os chãos que consideravam usurpados pelos lusos-brasileiros, em especial a aldeia de Santa Rosa.

Intimaram D. Antônio a evacuá-la. E pássando depois à ação ante a recusa do Capitão-General, em abril de 1763 atacaram a Capitania. D. Antônio encontrava-se no destacámento de Nossa Senhcra da Conceição, posição que fortificava e sucedia à aldieia de Santa Rosa. Estala a guerra na península. O ataque espanhol era uma consequiência dêsse estado de coisas. Os choques armados não deram, porém, vitória a qualquer dos contendutes. Por fim, recebida a comunicação da paz entre as duas mor:arnuias, retiraram-se os espa- 
nhóis, sem os resultados que imaginavam. $\mathrm{E}$ isso porque $\mathrm{D}$. Antônio não lhes entregou um só palmo da terra que estava governando.

Pouco depois, D. Antônio era ag aciado com o título de Conde de Azambuja, promovido ao pôsto de marechal de campo e transferido para a direção da Capitania Geral dia Bahia. Cumprira o dever: organizara o setor administrativo que lhe fôra confiado, defendendo-o da cobiça estranha. Seu sucesscr, como se comportaria? Teria a mesma envergadura cívica frente aos problemas de govêrno e aos problemas criados pela vizinhança incômoda?

Os desentendimentos na Ibéria criaram o problema da garantia e do estado de alerta na vasila fronteira do Paraguai - Guaporé - Mamoré - Madeira. João Pedro da Câmara, 2. $0^{\circ}$ Capitão-General entrega-se ao prosseguimento do progama de domínio da orla fronteiriça. Sua figura quase desconhecida. O que dizem os historiadores regionais. Calógeras quase o ignorou. Sua correspondência com o Capitão-General do Grão-Pará e Maranhão. Seu govêrno. Sua envergadura marcial face à invasão espanhola.

$\mathrm{O}$ sucessor de D. Antônio e seu scbrinho foi o tenente-coronel João Pedro da Câmara. Descendia dos descobridores da Madeira e Ilhas Desertas. Os historiadores dos fatos matogrossenses ou da formação territorial do Brasil não the prestaram ainda a conveniente justiça. Assim, Barbosa de Sá, Nogueira Coelho, Joaquim da Costa Siqueira, Beaureparie Rohan, Augusts Leverger e Estế, vão de Mendonça consagraram-lhe penadas rápidas, que não permitem compreender-lhe a posição na galeria magnífica dos Capitães-Generais de Mato Grosso. Vergílio Correia, que é o maior sabedor do passado de sua terra e está na obrigação de escrevê-lo nas minúcias em que é mestre, foi, de todos, o que mais the deu atenção, assinalando o papel que representou na luta pela posse da fronteira ameaçadia pelo castelhano.

Varnhagem, Handelman, Rio Branco, Calógeras, Pedro Calmon, se não o ignoraram de todo, fizeram-lhe referência quase nominal, como se tivesse sido apenas um ocupante passageiro do pôsto de govêrno com que $\mathrm{D}$. José o galardoara.

Sua passagem pela alta direção da Capitania, no entanto se não teve o brilho de $\mathrm{D}$. Antônio Rolim de Moura ou de Luís de Albuquerque de Melo Pereira e Cáceres, tão justamente do entusiasmo de Vergílio Correia, tampouco pode ser averbada entre a dos que se revelaram meros executores de ordiem. Sua passagem pela Capitania ocorreu em momento difícil, justamente quando as relações entre Portugal e Espanha perdiam a cordialidade para re- 
gressar ao estado de tensão que levaria a pronunciamentos armados. A Capitania fôra instalada há pouco e se via alvo do apetite dos hispano-americanos que não se conformavam com a perda territorial sofrida com a formação da nova unidade política luso-brasileira. D. Antônio lançara-lhe os fundamentos com muita segurança. Era necessário, porém, um continuador que consolidasse a obra memorável, agindo com habilidade, com energia e com perseverança, indiferente às dificuldades que surgissem e disposto a manter a situação com a recebera se não pudesse do todo ampliá-la. Ora, João Pedro da Câmara, como vamos ver, teve um comportamento dos mais dignos, de acôrdo com êsses imperativos, impondose, por isso à nossa simpatia, à nossa admiração.

Nomeado por carta patente de 16 de julho de 1763, chegara a Vila Bela a 25 de dezembro, de 1764, empossando-se a 1 de janeiro de 1765. Ao invés de atingir a Capitania pelo velho caminho das monções paulistas, viajou pelo Madeira. Era a primeira autoridade a utilizar o caminho fluvial que punha em contacto Mato Grosso com Amazônia e, por esta, com a Atlântico. Partira da Capital paraense a 7 de maio. Gastara, portanto, sete meses.

Em Belém, o Capitão-General do Pará, Fernando da Costa de Ataíde Teive Sousa Coutinho, deu-lhe tôda a cooperação: forneceu-lhe embarcações, guias, pessoal adestrado para a passagem das cachoeiras, recursos alimentares, além de um destacamento para refôrço da guarnição da Capitania e artilharia necessária à defesa do território (16).

Nas cachoeiras, João Pedro enfrentou a primeira dificuldade: a passagem das peças. No salto do Girau, deparou-se-lhe a tribo dos Pama, que desejava ali permanecer com aldeia devidamente conduzida por um religioso. João Pedro prometeu-lhe a ajudla. Entendeu, porém, que cabia ao govêrno do Grão-Pará a tarefa civilizadora, o que veio posteriormente a suceder.

Uma ve $z$ na direção da Capitania, procurou inteirar-se dos problemas com que devia defrontar-se. D. Antônio expôs-lhe a situação sem rodeios. Era suficiente? Naturalmente que as reflexões do tio, já experimentado na região, lhe haveriam de ser da maior valia. João Pedro, no entanto, militar, não ficou no que the era comunicado. E apressando-se a balancear a realidade matogrossense, logo compreendeu a gravidade da situação, sôbre que fêz as suas exposições ao Capitão-General do Pará e às autoridades em Lisboa. A paz que encontrara não lhe parecia uma paz longa . Havia que desconfiar. Ademais, os recursos da Capitania eram pre-

(16) . - A correspondência de Câmara com o governador Fernando da Costa de Ataíde Teive, do Pará, él copiosa e elucidativa. Guarda-se na sectrão de manuscritos da Biblioteca e Arquivo Públicos do Paará, códice Correspondência de Diversos com os Governadores. 
cários. Ante o insucesso anterior, os castelhanos se voltassem à luta seguramente, pela experiência adquirida, viriam com maiores fôrças, certos da fraqueza da resistência a lhes ser oposta.

João Pedro tratou, por isso, quanto antes, de preparar-se para a conjuntura militar que antevia. Pediu socorros a Belém e a Lisboa. A guarnição da Capitania reduzia-se à companhia de Dragões e à de Pedestres, que, no seu depoimento, era composta de

"soldados que andam descalços, armados de espingardas e uma pistola e um facão".

Esses soldados eram mulatos e se mostravam tão úteis na terra como n'água. Que the mandassem, no entanto, de preferência, oficiais, uma vez que, para as campanhas locais, o recrutamento devia fazer-se na própria região pelo conhecimento que os nativos possuiam de tudo, afeitos que estavam aos rigores tropicais. Os oficiais trariam os conhecimentos técnicos.

A antiga aldeia de Santa Rosa, onde D. Antônio principiara fortificação, constituía o ponto mais cobiçado pelos vizinhos. Era a estacada de Nossa Senhora da Conceição. Visitada a posição, cujas obras mandou incentivar, decidiu levantar uma praça de guerra. Tomando contacto com a realidade geográfica, para poder empreender a defesa da Capitania que $S$. Majestade the confiara, procurou informar-se do que representavam, do que valiam os vizinhos. Apurou então que as aldeias jesuíticas não se encontravam apenas integradas pelos contigentes indígenas, como seria normal. Em tôdas elas havia destacamentos militares. Um coronel de engenheiros, instalado no Itanomas, como que as supervizionava. $\mathrm{Na}$ aldeia de São Pedro, informaram-no os agentes que mantinha em atividade o presidente da Real Audiência de Charcas tomava iniciativas que não podiam deixar de levar à crença de que se preparava alguma ação militar. Não podia ser apenas, tôda a movimentação de que the chegavam notícias, uma movimentação objetivando a defesa, a estabilidade do território da Audiência ou da Província de Santa Cruz de la Sierra.

João Pedro, na evidência do que podia suceder, apressou as providências que os recursos locais the permitiam. Quando, em fins de 1765, recebeu de Francisco Xavier de Mendonça Furtado, Secretário do Estado para os Negócios do Ultramar, o avișo de 5 de julho para que se mantivesse em sobreaviso pois a situação na península era tensa, não se mostrou surpreso. Decidido, então, a agir com maior rapidez e intensidade, percorreu as zonas mais expostas: foi ao Guaporé e no chamado "sítio das Pedras" localizou uma guarda de 40 homens das fôrças de ordenanças da Capitania; passou, a seguir, aos rios Jaurú e Barbados, examinando as pos- 
sibilidade defensivas nos dois vales. Levantou uma rêde de fortins. Dirigindo-se ao Capitão-mor de Cuiabá ordenou-lhe que estivesse alerta. No primeiro momento imaginara que $o$ ataque pudesse incidir sôbre duas frentes: uma, partindo de Santa Cruz, sô bre Vila Bela ou Nossa Senhora da Conceição; outra saindo do Paraguai, sôbre Cuiabá. Informado pelo comandante de Nossa Senhora da Conceição de que os espanhóis se apresentavam com grandes contingentes em terra e sôbre o rio, ficou na certeza de que não tardaria a ação. Apelou para os governos de Goiás, Pará, São Paulo, Minas e Rio de Janeiro, solicitando-lhes reforços. E em junho, partiu com destino a Nossa Senhora da Conceição, confiando a defesa de Vila Bela a seu ajudante de ordens, para isso deixando-lhe um destacamento de 200 homens das ordenanças e elementos das companhiais de Dragões e Pedestres.

Em Nossa Senhora, as obras de fortificação não marchavam com rapidez à falta de material, principalmente cal. Imprimiu-lhes o dinamismo de sua presença e de sua vontade. Em breve, estavam concluídas e reforçada a guarnição com o contingente de 100 homens chegados de Belém. Era tempo. Porque a 1 de outubro, ano de 1766 , surgia o inimigo, que estacava a meia légua da margem ocidental do rio oposto à fortaleza. Seriam, circulou a noticia nos primeiros momentos, 4.200 homens, fardados de azul com canhões encarnados e vasto armamento, sob o comando de D. Juan de Pestana, Presidente da Audiência de Charcas ou Chiquisaca.

Como agir em face de tamanhas possibilidades do inimigo que parecia superior e capaz de uma partida vitoriosa? Bater em retirada para novas posições onde fôsse possível enfrentar o adversário, ou manter-se firme, decidido a lutar?

João Pedro, pouco antes, tomara a precaução de pôr em movimento 6 canoas armadas em guerra com duas pecinhas em cada e quatro bacamartes, e um bote com 30 soldados com uma peça de libra na proa e outra de $3 / 4$ na popa. O inimigo, da outra margem, para atingir Nossa Senhora da Conceição teria de passar o rio. A pequena fôrça embarcada poderia, porém, impedir a aventura? João Pedro decidiu resistir, disposto a morrer na defesa da Capitania .

Ouçamos, para melhor conhecimento do que foi a partida jogada pelos dois chefes militares, o espanhol e o portuguêş o próprio relatório dêste último, na exposição que remeteu a 28 de fevereiro, no local dos sucessos, a Fernando da Costa de Ataíde Teive, Capitão-General do Pará (17): (17). - Damos em apêndice o texto integral da exposição que, sôbre o episódio, fêz
Câmara ao governador Ataíde Teive. 
"Como sem passarem o Rio para a nossa parte não podiam fazer, senão algum dano, sem fruto; e vendo que lhes era impossível a passagem, pelos diferentes Destacamentos, que para impedi-la, eu havia postado com Artilharia: Assentaram imediatamente, que se levantasse uma bateria na ribeira do Rio, da sua mesma banda, para baterem a praça; que se faria fogo pelo espaço de duas horas; e que neste intervalo de tempo, mandaria eu naturalmente recolher tôda a gente que tinha por fora. Então que passaria o Coronel Engenheiro com gente, e Artilharia pelo lado esquerdo o que depois faria o mesmo o Presidente, pelo dado direito, para atacarem formalmente a Praça.

Esta idéia era excelente se se verificasse na prática; porém eu que considerava ser o ponto mais importante, impedir a passagem aos castelhanos, para a nossa parte, estava tão longe de mandar recolher os Destacamentos que os reforcei mais, com ordem aos Oficiais, que fizessem a sua obrigação, até morrer o último soldado e em todos reconheci valor para o fazerem.

Para a execução do seu projeto, mandou imediatamente o General Espanhol, marchar uma Companhia de Granadeiros, três de Fuzileiros e cem cavalos, a ocupar o sítio de Santa Rosa Nova duas léguas abaixo desta Fortaleza, destinado para a passagem do Coronel Engenheiro. Depois fêz marchar as outras tropas para a margem do Rio, que confronta com a mesma Fortaleza. Entraram com grande diligência na construção de balças, capazes de transportar para a nossa parte a gente e Artilharia; em fazerem a sua trincheira e bateria; a qual concluiram pondo nela oito peças de bronze, 4 de calibre de $8 ;$ e 5 de calibre de 6 . Além disto abriram uma grande vala, por detrás da mesma bateria, em que pretendiam segurar os seus soldados, para não serem ofendidos dos tiros da Praça.

No dia 12 chegou nela um Desertor, e referiu tôdas estas coisas e que estavam muito próximos os castelhanos a bater a Fortaleza. A 21 veio outro, que afirmou dar-se princípio ao ataque na manhã seguinte. A 22 se passou outro, e referio, que naquele dia se havia de bater a Praça; porém que tendo chegado um Postilhão de dentro ao General na noite antecedente, mandara êle retirar a Artilharia, desmanchar a trincheira, e entupir a Vala; e que passara ordem para se retirarem as Tropas. A 23 assegurou outro Desertor, que já a Artilharia ia em marcha; e que haviam queimado os reparos dela, com outras bagagens, que lhes podiam embaraçar a retirada. Tudo foi confirmado, não só pelos ditos dos Desertores, que passavam sucessivamente, mas também, por se ver cada dia menor número de soldados; até que no último do mesmo mês ficou a fronteira totalmente livre de castelhanos. 
Não consenti que se lhes atirasse, nem um tiro, e êles fizeram o mesmo, enquanto se ocuparam nos referidos trabalhos; os quais fizeram dentro no mato; poupando para a ocasião do ataque as munições. Era preciso que assim o fizesse; porque me achava com pouco quantidade de balas; e me foi forçoso mandar fazer algumas de bronze, valendo-me de sinos velhos.

Pelas manobras que fêz aquêle General, vindo manter-se em um lugar pantanoso, rodeado de mato, me parece ser pouco instruído na Arte da Guerra; e se chegasse a rompê-la, tinha em grande esperança de ficar senhor de sua Artilharia, e de passar muita parte de sua gente a espada".

Falhara a segunda tentativa hispano-americana para a conquista da Capitania, operação para qual se haviam preparado durante dois anos. O sucessor de Pestana, na Presidência da Audiência, D. Juan Vitoriano Martines de Tineo, dirigindo-se a João Pedro da Câmara em 15 de dezembro de 1767, comunicava-lhe proposta de paz.Voltava a insistir no abandôno da Fortaleza, que devia ser devolvida. Ora, justamentee a essa altura chegavam ordens de Mendonça Furtado para que houvesse entedimento harmônico com os vizinhos, mas que a fortaleza fôsse sustentada e melhor aparelhada, pois só dêsse modo seria possível manter tranquiilidade e ser respeitaido.

João Pedro, a quem, batendo a mesma tecla, também escrevera D. Antônio de Aymerich, corenel-engenheiro, comandante substituto das fôrças espanholas, respondeu aos dois garantindo-lhes o desêjo que o animava de uma boa vizinhança. Quanto à destruição da fortaleza, que era a menina de seus olhos, não tinha por que aceitar o pedido, tanto mais quanto nenhuma ordem nesse sentido recebera de $\mathrm{S}$. Majestade o rei $\mathrm{D}$. José .

Voltariam para a nova partida os atacantes? O receio idecorrera realmente daquelas razôes que o Capitão-General afirmara? A vastíssima documientação que vem sendo divulgada e a que se guarda nos arquivos espanhóis, recentemente sumariada pelos padres jesuítas Pablo Pastells e F. Mateo, bem como o que consta da "Memoria de Gobierno, do Vice-rei do Perú, D. Manuel de Amat y Junient (18)", esclarecem devidamente. O insucesso das armas espanholas, nos dias de D. Antônio Rolim de Moura, exasperara as autoridades da Audiência, do Vice-reinado do Perú e de Madrí. Uma cédula régia, expedida em 4 de setembro de 1764 , ordenara a segunda expedição: os portuguêses fôssem expulsos e reconduzidos ao que lhes fixara o Tratado de Tordesilhas! Santa

(18). - Cf. Manuel de Amat y Junieft — "Memoria de Gobierno" e Pastells, ob. cit., tomo VIII, 2a. parte. 
ingenuidade. Haviam sido mobilizados as forças de tôdas as Províncias lindeiras e interiores como se fôsse para uma guerra santa. A fôrça atacante, na verdade, de 2.500 homens, reduzira-se, porém, pelas enfermidades de que se vira assaltada, a 758, com duas baterias de artilharia. O ataque estava marcado para 20 de outubro e devia constar do bombardeio da praça, seguido do assalto, quando chegaram ao acampamento cartas ide D. Pedro de Cevallos, de Buenos Aires, sugerindo a supressão das hostilidades: é que estaria chegando ao pôrto do Rio de Janeiro um navio mercante espanhol que conduzia riquíssimo carregamento de couros e mais de um milhão de pesos. Seguramente, com notícias do ataque, seria apressado. Convinha, pois, evitar a emprêsa militar. D. Juan Pestana reunira Conselho de Guerra que decidira suspender as operações. Eram más as condições da tropa, dia a dia dizimada pelas febres; havia falta de gêneros e o movimentos das águas dos rios ameaçava criar maiores embaraços. As perdas de vida elevavam-se. As deserções cresciam. Ademais, as fortificações levantadas por João Pedro haviam constituido uma tremenda surprêsa. D. Juan Pestana vira-se na contingência de ceder. Expusera tudo ao Vice-rei. E batera em retirada, vindo a falecer, meses depois, em Chuquisaca. Ia ser submetidio a Conselho de Guerra por ordem de Lima, onde as razões que apresentara não haviam convencido. De Madrí, estava, então, chegando, uma cédula régia, datada de 4 de julho de 1766, pela qual o soberano Fidelíssimo mandava suspender a solução armada do conflito de fronteira, que devia ser cogitado e decidido pelo entendimento pacífico dos diplomatas e não pela fôrça das armas.

João Pedro da Câmara estava agindo, pois, como devia. Os assaltantes teria coragem, depois de tudo aquilo, de ensair novo ataque? O que mandava dizer sôbre a paz em que desejavam manterse não merecida confiança. João Pedro, em conseqüência, prosseguiu na tarefa da vigilância da fronteria e no melhor aparelhamento de Nossa Senhora da Conceição. Durante quase todo o ano de1766 mantêve-se na fortaleza onde se vira atacado. Às reclamações do Presidente da Audiência da Charcas e do Governador de Moxos não deu atenção. Dispunha agora de reforços virìo do Pará, que não faltava a Mato Grosso nas horas difíceis que vivia.

Em 3 de janeiro, chegando o Capitão-General Luís Pinto de Coutinho, que o vinha render na direção da Capitania, entregouthe o Govêrno. Dirigira a Capitania apenas três anos, esforçando-se por bem exercer o poder. Militar, encontrara uma situação difícil que êle próprio nos setores da fronteira considerara "miserável estado". Atendera à situação com energia e objetividade. Seus atos de govêrno, fora do campo bélico, foram inúmeros e praticados com 
segurança e acerto. Quizemos, aqui destacar-lhe, da personalidade, apenas aquêles aspectos que mais sabiam ao seu espírito marcial e o consagraram autêntico "fronteiro".

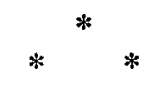

A decadência portugiguêsa no século XVIII não foi uma realidade quanto à grandeza e ao porte cívico dos soldadados e estadistas do ultramar. A galeria esplendorosa no Brasil. Os Capitães-Generais da Amazônia e do Mato Grosso. João Pedro da Câmara. "fronteiro" esquecido.

O século XVIII tem sido apontado como um século de crise, a encerrar-se com a grande revolução que deu ao Mundo as fórmulas já experimentadas com tanto êxito na Inglaterra. Em Portugal, essa crise viria do século anterior. Uma tremenda decadência aniquilava o país. Aquelas tradições magestosas do cíclo das navegações estavam esquecidas. Não falavam mais aos sentimentos nacionais.

A Restauração não constituia, no entanto, já de si, um sinal de que essa decadência não assumira as características negras que os historiadores liberais pretenderam ver no passado português de setecentos e oitocentos? O reinado de D. Pedro II, o de D. João V, o Consulado progressista de Pombal, já não nos é hoje dado vê-los mais claramente, como épocas de que se pode orgulhar Portugal, mesmo com as restrições que lhe devamos fazer? Pedro $\mathrm{II}_{b}$ executando uma política de manutenção da integridade territorial do império ultramarino; D. JoãoV realizando uma política de restauração da dignidade cultural do país; Pombal, tentando, com tôdas as fôrças, reformar a máquina do Estado e impulsionar econômicamente o Reino, acaso não se opuseram a que aquela decadência fôsse realidade?

No ultramar, de outro lado, a galeria dos vice-reis, dos Governadores, dos Demarcadores, dos Fronteiros, não se apresenta aos nossos olhos, à nossa curiosidade, à nossa indagação como uma uma galeria de figuras magníficas, de alto porte cívico, tão grandes como os heróis dos descobrimentos e das façanhas iniciais do Império na Îndia?

Os Antônio de Albuquerque Coelho de Carvalho, os Gomes Freire de Andrade, os João de Maya da Gama, os Francisco Xavier de Mendonça Furtado, os Manuel Bernardo de Melo e Castro, os João Pereira Caldas, os Joaquim de Melo e Povoas, os Manuel da Gama d'Almada, os D. Francisco de Sousa Coutinho, os José da Silva Paes, os Luís Pinto de Souza Coutinho, os Luís de Albuquerque de Melo. Pereira e Cáceres e tôda a outra imensa legião de ser- 
vidores menores que atuaram nas áreas nevrálgicas das fronteiras, não assumiram, na perspectiva do tempo, aquela significação de símbolos de bravura, de patriotismo, de espírito de sacrifício a serviço dos mais dignos ideais do Império ?

A decadência portuguêsa do século XVIII não constituiu uma realidade no ultramar. O porte cívico, insistamos, dos homens que Portugal expediu para o seu ainda imenso mundo imperial, revelou, contrário, a existência de uma seiva estuante. João Pedro da Câmara foi bem uma expressão dessa galeria de bons e leais servidores. Sua passagem por Mato Grosso, como vimos, na rapidez desta palestra, não the assegurou o nosso respeito a nossa admiração? Fronteiro olvidado, ao deixar o govêrno da Capitania, convenhamos, proclamemos, podia orgulhar-se, como fizera D. Antônio Rolim de Moura, de haver sabido cumprir o dever: mantivera íntegro o território que $\mathbf{D}$. José lhe confiara.

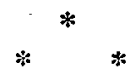

Illmo. e Exmo. Sr.

Tendo eu vindo a 18 de Dezembro do anno passado aesta Va. para dar varias providencias Necessarias, hoje Me chega avizo do Commandante da Fortaleza de N. Sra. da Conceição que os Castelhanos estão proximos aatacar aquell Portaleza, trazendo hú grande Numero degente, eArtilharia.

Pelo que sou obrigado apedir aV. Exa. que Me soccorra com maior numero degente, eofficiaes, que lhefor possivel, sem embargo deeu ter só pedido tres Officiaes, e 70 Soldados.

Ao Sargento Mor João deSousa deAzevedo faço avizo, pa. que não passe aArtilharia, nem a Polvora depenultima Cachoeira para cá, sem mandar primeiro explorar mto. bem o Rio Mamoré.

EstaCapitania se acha muito falta de Gente, Armas, e Muniçoens deGuerra edeboca; porem hei de comprir comaminha obrigação, defendendo esta fronteira até aultima extremidade.

Remetto aCarta incluza, eespero que V. Exa. me faça a Me. de aremetter logo para aSecretaria deEstado.

Deos Ge. aV. Exa. Va. Bella a17 de Fevro. de $\mathbf{1 7 6 6 .}$

João Pedro daCamara

Illmo. eExamo. Sr. Fernando daCosta

de Ataide Teive.

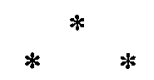

Illmo. e Exmo. Snr.

Tendo dado conta a V. Exa. de haverem os nossos Vezinhos marchado para esta Fronteira, com grandes forças do Peru, e de 
S. Cruz; as quaes dividirão pelas suas Missoens; agora o farei dos seus progressos, depois que sahirão dellas.

No primeiro de Outubro, chegarão ao sitio da Estancia, meia legoa distante da margem occidental do Rio, oposta aesta Fortaleza. Alli se abarracarão, constando o seu Exercito de 4200 homens, todos uniformemente fardados de azul, com canhões encarnados, e com muito bons Armamentos; sendo o General, que os governava o Presidente da Real Audiencia de Chuquisaca. Este veio examinar a nossa Fortaleza, com hum Coronel Engenheiro; o qual affirmou que estava bem fortificada; que os Portuguezes erão curiosos: e que se não poderia tomar sem brecha.

Como sem passarem o Rio para a nossa parte, não podião fazer, senão algum damno, sem fruto; e vendo que lhes era impossivel a passagem, pelos differentes Destacamentos, que para impedilla, eu havia postado com Artilharia: Assentarão immediatamente, que se levantasse húa bateria na ribeira do Rio, da sua mesma banda, para baterem apreça; que se faria fogo pelo espaço de duas horas; e que neste intervllo de tempo, mandaria eu naturalmente recolher toda agente que tinha por fora. Então que passaria o Coronel Engenheiro com gente, e Artilharia, pelo lado esquerdo; e que depois faria o mesmo o Presidente, pelo lado direito, para atacarem formalmente a Praça.

Esta idea era excellente se se verificasse na pratica; porem eu que considerava ser $o$ ponto mais importante, impedir a passagem aos Castelhanos, para a nossa parte, estava tão longe de mandar recolher os Destacam.tos que os reforcei mais, com ordem aos Officiaes, que fizessem a sua obrigação, até morrer o ultimo soldado, e em todos reconheci valor para assim o fazerem.

Para a execução do seu projecto, mandou immediatamente o General Espanhol, marchar hua Companhia de Granadeiros, tres de Fuzileiros, e cem cavallos, a ocupar o Sitio de Sta. Rosa novva duas legoas abaixo desta Fortaleza, distinado para a passagem do Coronel Engenheiro. Depois fez marchar as outras. Tropas para a margem do Rio, que confronta com a mesma Fortaleza. Entrarão com grande diligencia na construção de balças, capazes de transportar para a nossa parte a gente e Artilharia; em fazerem a sua trincheira, e bateria; a qual concluirão, pondo nella oito pessas de bronze, 4 do calibre de 8 ; e 4 do calibre de 6 . Alem disto abrirão húa grande valla, por de tras da mesma bataria, em que pertendião segurar os seus soldados, para não serem offendidos dos tiros da Praça.

No dia 12 chegou a ella hum Desertor, e referio todas estas cousas, e que estavão muito proximos os Castelhanos a bater a F,ortaleza. A 21 veio outro, que affirmou dar-se principio ao ataque na manhaã seguinte. A 22 se passou outro, e referio, que naquelle dia se havia de bater a Praça; porem que tendo chegado hum Pontilhão de dentro ao General na noite antecedente, mandara elle retirar a Artilharia, desmanchar a trincheira, e entupir a valla; e que passaram ordem para se retiraram as Tropas. A 23 assegurou outro Desertor, que ja a Artilharia hia em marcha; e que havião queimado os reparos della, e outras bagagens, que Ihes podião embaraçar a retirada. Tudo se foi confirmando, não só pelos ditos dos Desertores, que passavão successivamente; mas tambem por se ver cada 
dia menos numero de Soldados; até que no ultimo do mesmo mes, ficou a Fronteira totalmente livre de Castelhanos.

Não consenti que se lhes atirasse, nem hum tiro, e elles fizerão - mesmo, em quanto se occuparão nos referidos trabalhos; os quaes fizerão dentro no mato; poupando para a occasião do ataque as Muniçoens. Era preciso que assim o fizesse; por que me achava com pouca quantidade de tallas, e me foi forçoso mandar fazer alguas de bronze, valendome de sinos velhos.

Pelas manobras que fez aquelle General, vindo meterse em hum lugar pantanoso, rodeado de mato, me parece ser pouco instruido na Arte da Guerra; e se chegasse a rompella tinha eu grande esperança de ficar senhor da sua Artilharia, e de passar muita parte da sua gente a espada.

Segundo todos os Desertores que ja vinhão seis Companhias distinadas para a Goarnição da Fortaleza depois de tomada e juntamente Governador nomeado, hum sobrinho de General de Sta. Cruz; que occupa o Posto de Capitão de Cavallos. Persuadirão se que vinhão achar esta Fronteira no mesmo mizeravel Estado, em que estava, quando tomei posse do Governo; porem depois que virão a Fortaleza, e os differentes Fortins, quemandei fazer, nos sitios que me parecerão convenientes ficarão esmorecidos.

Para me por neste estado nestes dois annos que tenho de Capitania não descancei hum só momento, não me fiando nestes maos vezinhos denominados Jesuitas. Não me enganei; porque agora estou certificado, que há tambem dous annos que se occupão em juntar esse exercito, e os mais petrecho Militares: tirando-se gente do Potosi, Cuchabanba, Chuquisaca, Sta. Cruz e de outras Cidades e lugares. Tambem a vinda do Presidente da Real Audiencia, que he superior aos Governadores; o qual não quiz vir na guerra passada, tendo crdem do Vice Rei de Lima para isso; dizendo, que só o devia fazer, tendo-a de El Rei; inculca o grande empenho de tomar a Fortaleza, e que foi determinação de Sua Magestade Catholica.

Não faltarão dizençoens entre os Officiaes e os chamados Missionarios, chegando estes a esconder o gado, e os cavallos, pelo que foi obrigado o Presidente a mandar Cavallaria buscar hua e outra cousa. Por esta causa padecerão os seus soldados bastantes fomes, e affirmão constante mente os Desertores, que chegara o dito Presidente a fazer conduzir a sua presença amarrado, hum dos taes Padres que se havia escondido no mato.

As suas Missoens não há duvida que ficarão arruinadas com a assistencia de tantas Tropas; e algúas inteiramente destruidas. A de São Martinho he húa dellas; passando para a nossa parte todos os seus Indios, excepto alguns poucos, que se derramarão pelos matos. Os da Missão de S. Simão matarão ao Pe. que os dirigia com veneno. Este bom Missionario, era hum dos que na guerra passada, affirmava, como cousa justa o uso de envenenar as flechas; e andava conduzindo grande numero dellas à estacada de Isonamas, para os Indios as empregarem nos nossos, como o fizerão.

No tempo em que as sobreditas Tropas Castelhanas se demorarão nesta Fronteira lhes morreo muita gente, sendo muito maior o numero do que retirarão doente. Este Clima com os seus maos effeitos, que produzce o melhor Auxiliar, que temos a nosso favor. 
Depois de tão repentina retirada, mandei hum Corpo sufficiente a examinar o campo, e alem de outras cousas, que apressa lhes não deo lugar a retirarem, se se acharão 62 cabeças de Gado, 10 Cavallos, e tres Mulas; e q. tudo fiz conduzir para a nossa banda; sendo-nos muito util este despojo, conseguido sem sangue.

Ultimamente chegou hum Desertor, com o seu Cavallo, que deo conta de se haverem destribuido outra vez as Tropas pelas Missoens, aonde adoecião e morrião com muita frequencia. Dizem todos estes Desertores, que a maior parte dos seus soldados, estavão com desejo de passarem para a nossa parte; porem que os embaçarava o grande aperto $\mathrm{em}$ que os seus Officiaes os tinhão. Dos nossos não houve algum, que tomasse tão feia resolução; antes todos estavão cheios de alegria, e desejosos de vir as mãos.

Isto he tudo o que tem acontecido nesta Fronteira até o presente. Deos queira que as cousas da Europa se ponhão em termos de que gozemos o Leneficio da Paz, que he a maior de todas as filicidades.

Deos g.e a V. Exa. Fortaleza de Nossa Senhora da Conceição 28 de Novembro de 1766 .

Illmo. e Exmo. Sr. Fernando da Costa

João Pedro da Camara.

de Ataide Teive.

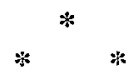

Illmo. e Exmo. Snr.

Depois de participar aV. Exa. os successos do anno passado nesta Fronteira, restame dizerlhe o que mais tem occorrido ate apresente. Como entrarão as agoas, tempo emque estava seguro de ser atacada a Fortaleza, fui à Capital a dar differentes providencias quepedião a Minha presença.

Alli mefoi remettida hua Carta de D. Antonio de Aymerich, Coronel Engenheiro, e Commandante das Tropas Espanholas, em ausencia do primeiro General o Presidente da Real Audiencia de Chuquisaca. Diziame nella haver recebido ordem de El Rei seu Amo, para que immediatamente suspendesse todo o ato da força, não duvidando do que eu praticaria omesmo, como era correspondente aboa armonia, e estreita união, que subsistia entre as duas Coroas, ficando a conclusão rezervada ao acordo reciproco, que irmaã mente sepraticaria pelos dous Soberanos. Em cuja consequencia me pedia quizesse dar ordem para sefranquear a Navegação do Rio Itenes.

Respondilhe que eu nunca tivera determinação algúa, que fosse contraria ao disposto no ultimo Tratado Definitivo da Paz, prevendome conforme o Direito das Gentes, para rebater qualquer impulso contrario, regulado unicamente pelos movimentos que havia percebido nas Tropas de Sua Magestade Catholica. Que tudo puzera naprezença do Meu Augustissimo Amo até cujo ponto menão havia chegado resposta algúa; porem que sem embargo disso, todas as vezes que elle Commandante fizesse retirar as ditas Tropas, eme restituisse os Prisioneiros; que erão: hum Cabo de Esquadra; hum Soldado Infante; / que oCap.m Com.o daTropa deixou perdido naCachoeira / e hum Indio; promptissimamente deixaria livre a Navegação mencionada: Promettendo guardar con religiosa observancia, o referido Tratado. 
Não respondeo até oprezente; equando eu esperava que elle tivesse effeito recorrido a Chuquisaca, para onde correo noticia, quesehavia retirado o Presidente, chegou a 15 do mes passado hum Desertor, que affirmou haver morrido, pouco tempo depois que chegou a Sta. Cruz, das Molestias, que adquerio nesta Colonia, com muitos outros Officiaes, eSoldados. Nestes termos creio que se esperará a solução do Vice Rei de Lima, aqual necessariamente hade tardar, pela Muita distancia em que esta situada junto... Pacifico aquellaCidade.

Poucas Tropas se achão já nas Missoens, cadaves Mais assolados; porem como não recebo ordem, nem noticia algúa de estarem pacificados as differenças, de nenhum modo posso desarmarme, expedindo o soccorro, tendo eupara este effeito demorado o Sargento mór Pratico Jozé deSouza até á chegada desta Canoinha.

Só tomo o expediente de mandar agora oCapitão Commandante João Batista Maratel, porque não foi possivel reduzillo a observar inteiramente as minhas ordens, naCommandancia destaFortaleza emque o deixei, quandofui á Capital, nem a conterse nos termos dadecencia escrevendome. Depois de o advertir dasua atrevida petulancia me dirigio aCarta inclusa, alem de outras, que não ponho na presença deV. Exa. por serem mais indignas.

Das duas contas: hua do Prov.or Commissario desta Fortaleza, e outra do Ajudante das Ordens de Goyaz, que veio com as Reclutas daquella Capitania, verá V. Exa. parte doprocedimento do dito Official, ficando oresto para quando voltarem os seus Camaradas.

Restame pedir aV. Exa. pelo grande favor $\mathrm{q}$. me faz que o não castique por estas desordens, nascidas do seu genio, altivo, desconfiado, fogozo, epouco constante. Todos os mais Officiaes tem procedido muito bem até opresente, pelo que estou bastante satisfeito.

Deos G.e aV. Exa. Fortaleza de N. Sra. da Conc.am a 4 de Setro. de 1767 .

P. S. Com aconfuzão depapeis não

......... descubrir a Carta em

q. fallo acima a V.E xa.

Illmo. e Exmo. Snr. Fernando daCosta deAtaide Teive. João Pedro daCamara.

ARTHUR CEZAR FERREIRA REIS

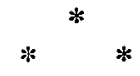

\section{BIBLIOGRAFIA}

Barão de Melgaço. - "Apontamentos cronológicos da Capitania de Mato Grosso". Revista do Instituto Histórico e Geográfico Brasileiro. Vol. 205, Rio, 1952.

Barbosa de Sá (José). - "Relação das povoações de Cuiabá e Mato Grosso, de seis principios até os presentes tempos". Anais da Biblioteca Nacional. Vol. XIII. Rio, 1904. 
Coelho (Felipe José Nogueira). - "Memórias cronológicas da Capitania de Mato Grosso". Revista do Instituto Histórico e Geográfico Brasileiro, tomo 13, 2. ${ }^{\circ}$ semestre. Rio, 1850.

Correa Filho (Vergílio). - Monografias cuiabanas. Evolução do erário. São Paulo, 1925.

Correa Filho (Vergílio). - Monografias cuiabanas. À cata de ouro $e$ diamantes. São Paulo, 1925.

Correa Filho (Vergilio). - As Raias de Mato Grosso. Vol. IV, São Paulo, 1926.

Cortesão (Jayme). - Alexandre de Gusmão e o Tratado de Madrí. Antecedentes do Tratado. Tomo II. Rio, 1951.

Juniett (Manuel de Amat y). - Memoria de Gobierno. Edição com estudo preliminar de Vicente Rodriguez Casado e Florentino Perez Embid. Sevilha, 1947.

Mendonça (Estêvão). - Datas matogrossenses.

Pastells (R. P. Pablo). - Historia de la Companhia de Jesus en la Proviniaia del Paraguay. Continuação por F. Mateos, tomos VI a VIII. Madrí, 1946-1949.

Reis (Arthur Cézar Ferreira). - Limites e Demarcaçôes na Amazônia Brasileira. A Fronteira com as colônias espanholas. $2 .^{\circ}$ volume, Rio, 1948 .

Rohan (Beaurepaire). - "Anais de Mato Grosso". Revista do Instituto Histórico de São Paulo, tomo XV, 1912.

Siqueira (Joaquim da Costa). - . "Compêndio histórico cronológico das notícias de Cuiabá" . Revista do Instituto Histórico e Geográfico Brasileiro, tomo XIII. Rio, 1850 .

Siqueira (Joaquim da Costa). - "Crônicas do Cuiabá". Revista do Instituto Histórico de São Paulo, tomo IV. São Paulo, 18981899 .

Taunay (Afonso). - História das Bandeiras Paulistas, tomos IV, VI e X. São Paulo, 1928, 1939, 1949.

Correspondência com os Governadores. Códice da secção de manuscritos da Biblioteca é Arquivo do Estado do Pará.

Correspondencia dos Governadores de Mato Grosso. Códice da secção de manuscritos do Instituto Histórico e Geográfico Brasileiro. 